\title{
Simulación de procesos constructivos
}

\section{Simulation of constructive processes}

\author{
Adriana Gómez Cabrera*1 \\ * Pontificia Universidad Javeriana. COLOMBIA \\ Fecha de recepción: 22/ 01/ 2010 \\ Fecha de aceptación: 11/ 03/ 2010 \\ PAG. 121 - 141
} \begin{abstract}
Resumen
Este trabajo presenta la simulación de eventos discretos como una herramienta para la planeación, reingeniería y el análisis de proyectos de construcción partiendo de un caso real consistente en el proceso constructivo de una estructura en concreto reforzado que incluye cimen-tación, pedestales, vigas, placa de entrepiso y columnas. Inicialmente se llevó a cabo una labor de campo, donde para cada actividad se registró la duración, las cantidades de obra, los recursos in-volucrados y las detenciones. Con base en esta información se diseñó un modelo de simulación en el software Arena, respetando la secuencia de actividades, distribuciones de probabilidad defi-nidas para los procesos y los recursos utilizados. El modelo trabaja a través de una interfaz con Microsoft Excel y macros desarrollados en Visual Basic, a través de la cual se le facilita al usua-rio el ingreso de los datos de entrada (fecha de inicio del proyecto, Ilegada de los materiales, entre otros). La simulación controla la duración de actividades, utilización de recursos y consumo de materiales. Esta integración de herramientas permite simular diferentes escenarios para el proyec-to y analizar oportunidades de mejora asignando diferentes atributos a variables que afectan el proyecto como: fecha de inicio de actividades, disponibilidad de recursos y materiales, entre otros.
\end{abstract}

Palabras Clave: Simulación digital, software arena, procesos constructivos, eventos discretos, re-ingeniería.

Abstract

This paper presents the simulation of discreet events as a tool for the planning and the analysis of construction projects based on a case study of the constructive process of a reinforced con-crete structure that includes the foundation, pedestals, beams, a slab and columns. Initially a field work was carried out to register duration, resources and delays for each activity. Based on this information a simulation model in the software Arena was developed. The sequence of the activities, probability dis-tribution functions defined for the processes and the resources used were included for each activity. The model works through an interface with Microsoft Excel and macros developed in Visual BASIC, through which the user can easily introduce the input data. The simulation controls the duration of ac-tivities, use of resources and consumption of materials. This integration of tools allows simulating dif-ferent project scenarios permitting to analyze improvement opportunities assigning different attributes to the variables that affect the project such as activities begin date, availability of resources and materi-als, among others.

Keywords: Digital simulation, software arena, construction processes, discrete events, reengineering

\section{Introducción}

Los constructores de proyectos civiles permanentemente se ven enfrentados al reto de aumentar la pro-ductividad con el fin de balancear las variables tiempo y costo. En este documento se plantea la aplicación de la simulación de procesos constructivos apoyada en la herramienta computacional Arena, a tra-vés de la cual se logra una imitación de los procesos constructivos, permitiendo analizar diferentes escenarios respecto a cantidad, tipo de recursos e interacción entre los mismos.

\section{Introduction}

Civil project constructors are permanently facing the challenge of increasing productivity, in order to balance cost and time variables. This paper proposes the implementation of a constructive process simulation supported by the Arena software, through which an imitation of constructive processes is achieved, thus allowing analyzing different scenarios regarding amount, type of resources and interaction among them.

\footnotetext{
1 Autor de correspondencia / Corresponding author:

E-mail: adrianagomez $@$ javeriana.edu.co
} 
Arena es una herra-mienta para simulación de procesos, cuyo origen se remonta al año 1982 cuando Dennis Pegden publi-có un lenguaje de simulación para modelar sistemas de manufactura (Fabregas et al., 2003), que en 1993 fue introducido como Arena, herramienta que permite crear modelos a través de ambientes gráfi-cos e interactivos con el fin de simular áreas especificas de los procesos de producción, o en este caso de construcción. Arena es una aplicación del sistema operativo Windows, compatible con Excel y Ac-cess, diseñada para su empleo en todas las funciones de sistemas productivos, permitiendo el análisis detallado de los procesos y de los recursos utilizados para la ejecución de los mismos, mediante una re-presentación gráfica del proceso modelado tipo "diagrama de flujo".

En este artículo se presenta un modelo que tiene en cuenta las variables que intervinieron en un proyecto real y se generan diferentes escenarios que brindan herramientas para la toma de decisiones respecto a métodos constructivos y recursos involucrados, con el fin de minimizar el costo y la duración.

Respecto a antecedentes, en Ingeniería Civil se han realizado investigaciones desde la década del $\mathbf{9 0 ,}$ con el fin de simular los procesos constructivos y contar con una herramienta útil para la toma de deci-siones. Algunas de estas investigaciones son las siguientes: - Lu (2003) propone la simulación como herramienta para predecir rendimientos en obra a través de la herramienta SDESA (Simplified discrete-event simulation approach for construction simulation) desarrollada a través del software Access, la cual es aplicada a la construcción de pavimentos. Poste-riormente SDESA fue ampliada para permitir una simulación mas real, permitiendo un ambiente en $\mathbf{3}$ dimensiones y Lu y Wong (2005), hacen una comparación entre el software PROMODEL y la herra-mienta SDESA para modelar actividades típicas de construcción.

- Lu et al. (2006) proponen utilizar esta misma herramienta para manejar los desechos en obra, provenientes de demoliciones y de construcción; con el fin de determinar la rentabilidad de la clasifica-ción de residuos en la fuente.

- Sacks et al. (2007) utilizan la herramienta Stroboscope, modelando mediante eventos discretos para la gerencia de la construcción de edificios altos de apartamentos en el cual los diseños se ajustan a las necesidades específicas de los clientes. Se plantearon diferentes escenarios de manera similar a un juego de roles, el cual fue desarrollado en la realidad y después representado en el modelo computacio-nal.
Arena is a tool developed to simulate processes, whose beginning goes back to 1982, when Dennis Pegden published a simulation language to model manufacture systems (Fabregas et al., 2003), later in 1993 it was introduced as Arena, a software that enables the creation of models on graphic and interactive environments in order to simulate specific areas of productive processes or, in this case, construction processes. Arena is an application on Windows operational system compatible with Excel and Access, designed to be used within all functions of productive systems, allowing a detailed analysis of processes and resources employed in the execution of them, by means of a graphic representation of the modeled process, the "flow chart".

This article introduces a model that takes into consideration the variables involved in an actual project and creates different scenarios that provide tools for decision making on constructive methods and involved resources, in order to reduce the cost and duration.

As background, Civil Engineering field has conducted researches since 1990's, so as to simulate constructive processes and to obtain a useful tool for decision making. Some investigations are:

- Lu (2003) proposes simulation as a job-site prediction tool, by using the SDESA (Simplified discreteevent simulation approach for construction simulation), developed by the Access software, which is applied on construction pavements. Later, SDESA was enlarged to allow a more realistic simulation, providing a 3dimensions environment. Lu and Wong (2005), compare the PROMODEL software with SDESA tool in order to model typical construction activities.

- Lu et al. (2006) propose the use of this same tool to handle waste material in job site, originated by demolitions and constructions, in order to find the profitability of residual classification in the source.

- Sacks et al. (2007) uses the Stroboscope tool, modeling though discrete events the construction management in high apartment buildings, whose design met the clients's specific requirements. Different scenarios were proposed by using a sort of role play, which was actually conducted and then represented by a computer model. 
- Chang y Lu (2008) proponen la herramienta para el manejo de materiales durante la construc-ción de un viaducto. Este método consiste en un algoritmo que selecciona la mejor opción entre varias posibles, pero no garantiza que esta sea la óptima.

- Mao y Zhang (2008), proponen hacer reingeniería de procesos constructivos integrando princi-pios de Lean construction y simulación digital. Mediante la observación de procesos constructivos se proponen acciones de mejora siguiendo los principios "lean", las cuales son posteriormente modeladas a través de simulación con un software especializado en construcción Il amado "Simphony". A nivel latinoamericano, algunas de las investigaciones desarrolladas son:

- Sosa et al. (2007), plantean un modelo para simulación computarizada del proceso constructivo de la losa prefabricada, empleando la herramienta Stroboscope, el cual permitió hacer una comparación entre métodos de construcción de losas, para optimizar los tiempos y los costos en función de la canti-dad de los recursos empleados.

- Baeza et al. (2004), analizan la aplicabilidad de los sistema de simulaciones en el estudio de la productividad de la mano de obra mexicana. Se emplearon sistemas de simulaciones para procesos tan-to homogéneos (STROBOSCOPE-CPM), como no homogéneos (DATSIMSUPER - orientado a obje-tos). Se determinó hasta qué grado estas dos tecnologías de simulaciones computacionales son capaces de predecir los niveles de productividad de métodos aplicados a la construcción de vivienda de interés social mexicana.

- En Colombia, se han desarrollado desde 1996 investigaciones de simulación en la Universidad de los Andes, apoyadas en los software Micro cyclone (López, 1996) - (Ballesteros, 1998), Strobos-cope (Navarro, 2001) y Arena, (Páez, 2007) - (Mesa, 2008) y (Echeverry et al., 2008). En estas inves-tigaciones se ha buscado diseñar modelos que permitan imitar los procesos constructivos, con el fin de optimizar los recursos involucrados en los mismos, aumentando la productividad mediante la disminu-ción en tiempos y costos.

\section{Descripción del proyecto}

El proyecto objeto de este estudio consiste en una edificación tipo bodega de un piso y mezanine, con área aproximada de $600 \mathrm{~m}^{2}$ como se muestra en la Figura 1. La estructura se construyó en concreto re-forzado,
- Chang and Lu (2008) propose the tool for material handling during a viaduct construction. This method consists of an algorithm that selects the best among several possible options, but it does not guarantees it is the optimal one.

- Mao and Zhang (2008), propose to conduct a constructive processes reengineering by integrating Lean's construction principles and digital simulation. By means of an observation of constructive processes, actions improvement is proposed following "Lean" principles. The actions are then modeled by a software simulator specialized in construction, the so called "Simphony".

Some investigations developed in Latinamerica are:

- Sosa et al. (2007), propose a computer simulation model for the constructive process of a precast slab, using the Stroboscope tool, which enabled a comparison among slab construction methods, so as to improve time and costs, in function of the amount of involved resources.

- Baeza et al. (2004), analyze the applicability of simulation systems for the study of productivity in Mexican skilled labor. Either homogeneous (STROBOSCOPE-CPM) or non-homogenous (DATSIMSUPER - oriented to objects) process simulation systems were used. It was determined the extent in which both computer simulations technologies are able to predict productivity levels in methods applied to social housing construction in Mexico.

- In Colombia, investigations have been conducted since 1996 by Universidad de los Andes, supported by softwares Micro Cyclone (López, 1996) - (Ballesteros, 1998), Stroboscope (Navarro, 2001) and Arena, (Páez, 2007) - (Mesa, 2008) and (Echeverry et al, 2008). These investigations intend to design models enabling the imitation of constructive processes in order to optimize the resources involved in these processes, thus increasing the productivity by reducing time and costs.

\section{Project description}

The project currently studied consists of a standard ground floor warehouse building and mezzanine of $600 \mathrm{~m}^{2}$ approximated area, as shown in Figure 1. The structure was built in reinforced concrete, 


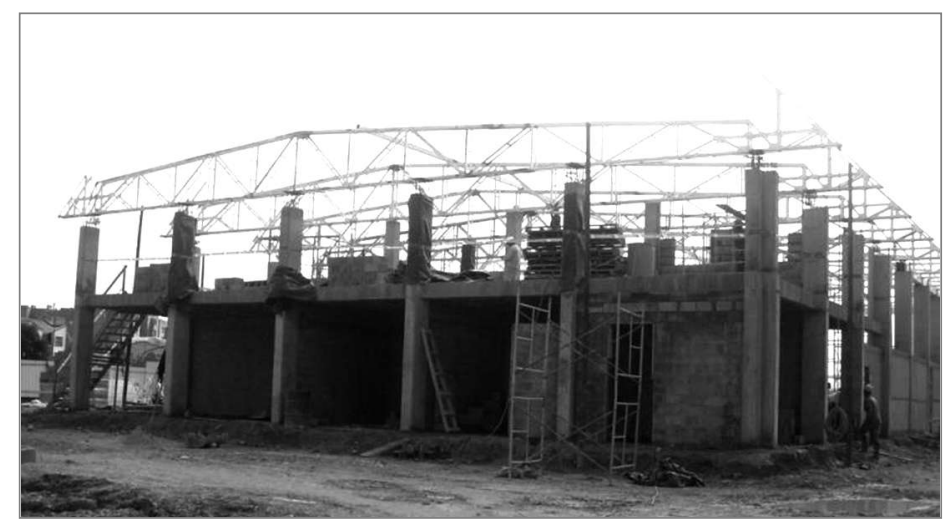

Figura 1. "Imagen del proyecto"

Figure 1. "Project Picture"

Para el desarrollo del proyecto inicialmente se definió el tipo de actividades a simular, teniendo en cuenta que se repitieran en el futuro y poder así aprovechar las acciones de mejoramiento.

\section{Metodología}

Para el desarrollo de la modelación de la construcción del proyecto, se realizó la identificación de los procesos constructivos a simular mediante visitas de obra y estudio de los documentos del proyecto. Los pasos se describen a continuación:

- Seleccionar las actividades para las cuales se iba a realizar la simulación, estas fueron construcción de zapatas, vigas de cimentación, columnas y placa de entrepiso, teniendo en cuenta que son las que agregan valor al proyecto.

- Definir la secuencia de actividades para elaborar un modelo gráfico, mediante análisis de los do-cumentos del proyecto y observación directa de actividades; y a la vez registrar manualmente y en campo los datos en un formato diseñado para tal fin que permite registrar para cada ítem de obra: acti-vidad en ejecución, duración total, cantidades de obra ejecutadas, recursos físicos involucrados (herra-mientas y equipos), personal involucrado (oficiales y ayudantes) y detenciones. En el caso de las deten-ciones se incluyen los motivos que las generaron como por ejemplo el clima, la falta de materiales, el número de personas en la obra, etc. Un ejemplo de este formato se muestra en la Figura 2.
For the project development the kind of activities to be simulated were initially defined, taking into account that they had to be repeated in the future, in order to take advantage of improvement actions.

\section{Methodology}

For the development of the construction project modeling, an identification of constructive processes to be simulated was conducted, by means of job-site surveys and the study of construction documents. Steps are described below:

- Selection of activities to be simulated, which are the construction of footings, foundation beams, columns and slabs, considering that those aggregate value to the project.

- Definition of activities sequences, in order to create a graphic model by means of an analysis of the project documentation, and a direct survey on activities. At the same time, the manual registration at the job-site of every item in the field: activity in progress, total duration, amount of executed work, physical resources (tools and equipment), involved staff (officers and assistants) and standstills. For the case of standstills, the reasons were included such as weather conditions, lack of material, headcount at the job-site, etc. An example of this format is shown in Figure 2. 


\begin{tabular}{|c|c|c|c|c|c|c|c|c|c|c|}
\hline \multicolumn{11}{|c|}{ ZAPATA TIPO 2 EJE A - 1/FOOTING TYPE 2 A-1 } \\
\hline CANTIDAD/QTY & ACTIVIDAD/ACTIVITY & $\begin{array}{l}\text { HERRAMIENTAS Y EQUIPOS/ } \\
\text { TOOLSAND EQUIPMENT }\end{array}$ & $\begin{array}{l}\text { OFICIAL/ } \\
\text { OFFICER }\end{array}$ & $\begin{array}{l}\text { AYUDANTE } \\
\text { ASSISTANT }\end{array}$ & $\begin{array}{l}\text { FECHAINGIO/ } \\
\text { BEGINNINGDATE }\end{array}$ & $\begin{array}{l}\text { FECHAFN } \\
=\text { ENDINGDATE }\end{array}$ & $\begin{array}{l}\text { HORA INICIO } \\
\text { BEGIN-NING } \\
\text { TIMF }\end{array}$ & $\begin{array}{l}\text { HORA FIN } \\
\text { ENDING } \\
\text { TIMF }\end{array}$ & $\begin{array}{l}\text { HORAS TOTAL DE EJECUCIÓN, } \\
\text { TOTAL EXECUTION HOURS }\end{array}$ & DETENCIONES/STOPS \\
\hline \multirow{3}{*}{$8.586 \mathrm{~m}^{3}$} & $\begin{array}{l}\text { EXCAVACIÓN } \\
\text { MECANICA/ } \\
\text { MECHANICAL } \\
\text { EXCAVATION }\end{array}$ & $\begin{array}{l}\text { Retroexcavadora } \\
\text { /Back loader }\end{array}$ & & & 28-oct-08 & 28-oct-08 & 4:00p.m & 4:30p.m & 0.5 & \\
\hline & $\begin{array}{l}\text { EXCAVACION } \\
\text { MANUAL/ } \\
\text { MANUAL } \\
\text { EXCAVATION }\end{array}$ & $\begin{array}{l}1 \text { Pala/ } 1 \text { shovel } \\
1 \text { Pica y } 1 \text { barra (turnada } \\
\text { en tres areas de } \\
\text { excavación)/ } 1 \text { pike, } 1 \text { bar } \\
\text { (in three excavation areas) } \\
1 \text { escalera de mano/ } 1 \\
\text { hand ladder }\end{array}$ & & 1 & 28-oct-08 & 29-oct-08 & 4:30p.m & 6:00p.m & 16 & $\begin{array}{l}\text { Octubre/October 29: } \\
\text { 7:00a.m-m: } 4 \text { a a.m. personal en construcción } \\
\text { de campamento y uartos de trabajadores } \\
\text { staff at canstruction field and workers dormitories } \\
\text { 12:00m - 1:00p.m: Descanso/work break } \\
\text { 3:00p.m - 3:20p.m: Descanso/work break }\end{array}$ \\
\hline & $\begin{array}{l}\text { PERFILADO } \\
\text { FINAL/ } \\
\text { FINAL LEVELING }\end{array}$ & $\begin{array}{l}1 \text { Pala/ } 1 \text { shovel } \\
1 \text { Picay } 1 \text { barra (turnada } \\
\text { en tres areas de } \\
\text { excavación)/ } 1 \text { pike, } 1 \text { bar } \\
\text { (in three excavation areas) } \\
1 \text { escalera de mano/1 } \\
\text { hand ladder }\end{array}$ & 1 & 2 & 30-oct-08 & 30-oct-08 & 7:00a.m & 10:00a.m & 2.7 & $\begin{array}{l}\text { Octubre/October 30: } \\
\text { 9:00a.m - 9:20a.m: Descanso/work break }\end{array}$ \\
\hline
\end{tabular}

Figura 2. "Formato de toma de datos"

Figure 2. "Data Collection Format"

- Organizar los datos por actividad y por ítem y elaborar las curvas de distribución de probabili-dad para los casos en que se contaba con el número de datos suficientes (mínimo 10). Con estos datos se graficaron los histogramas del comportamiento de los datos, que sirvieron para definir la curva de distribución de cada actividad en particular. Esta actividad se realizó con la herramienta Input Analizer de Arena - Rockwell Software, la cual brinda las distribuciones que mas se ajustan a los datos y reali-zan las pruebas de bondad y ajuste Chi-cuadrado o Kolmogorov-Smirnov según el número de datos. Se seleccionó la distribución que cumpliera con los parámetros de prueba (p-valor > 0.15).

- Para los casos en los cuales no se contaba con datos suficientes, se optó por acudir a la opinión de expertos para la estimación de tiempos en escenarios optimista, pesimista y mas probable. Fueron consultados los profesionales y trabajadores de la obra. Con estos escenarios se generó en el Input Ana-lizer una distribución triangular.

- Definir la estructura del modelo. En esta actividad se estableció que las entidades serían las za-patas, pedestales, vigas, columnas y placa de entrepiso. Se decidió hacer una interfaz con la herramien-ta Microsoft Excel, a través de la cual se ingresan las fechas de inicio de las zapatas, siendo esta la acti-vidad con la que inicia el ciclo. Esta herramienta permite que el planeador del proyecto pueda ingresar la fecha de inicio de cada zapata y su ubicación según el plano (Ejes X-Y). Mediante la utilización de la herramienta Visual Basic, se generan filas de datos con el tipo de zapata, identificación, día de inicio y número de zapatas que ingresan por día.
- Organizing data by activity and item and to elaborate probability distribution curves for cases counting with enough amounts of data (minimum 10). Such data were used to elaborate data behavior histograms, useful to define the distribution curve for each particular activity. This activity was performed by using the Input Analyzer tool of Arena - Rockwell Software, which provides the most adjusted data set distributions, and develops Chicuadrado or Kolmogorov-Smirnov goodness of fit and adjustment tests, according to data set amount. The chosen selection was the one meeting all test parameters (p-value $>0.15)$.

- For cases not counting with data enough, the option of consulting the experts' opinion was selected in relation to time estimation for optimistic, pessimistic and most probable scenarios. Professionals and workers at the job site were interviewed. From these scenarios, a triangular distribution was created by the Input Analyzer.

- Definition of model structure. This activity established that entities would be footings, pedestals, beams and slabs. It was decided to create an interface under Microsoft Excel tool, where footings beginning date would be entered, being this activity the beginning of the cycle. This tool allows the project designer to enter the beginning date of each footing and its location in the drawing (X-Y). By employing a Visual Basic tool, data rows are created with the type of footing, beginning day and number of footing entered by day. 
Estas columnas de datos son la entrada al modelo de Arena, así como otro archivo en el que se generaron las fechas de llegada de los materiales al proyecto, también utilizando la herramienta Microsoft Excel.

- Elaborar el modelo en el software Arena, siguiendo la secuencia de actividades, las distribucio-nes de probabilidad definidas y los recursos registrados utilizando herramientas básicas y avanzadas del programa.

- Hacer la validación de la información obtenida en el paso anterior con el análisis de la las dura-ciones de actividades y del proyecto en general comparadas con las observadas en campo. También se consultó al personal de obra para la aprobación de los datos obtenidos.

- Generar nuevos escenarios que permitan observar el comportamiento frente a las variaciones respecto a: saturación del suelo, fechas de inicio zapatas, fechas llegada materiales, disponibilidad de recursos por día, etc.

\section{Desarrollo del modelo}

El software Arena trabaja mediante simulación gráfica y módulos de análisis que crean un sistema compuesto por entidades a las cuales se les asignan atributos para ser individualizadas para después ser sometidas a eventos que suceden en el tiempo. Adicionalmente se asignan variables que reflejan características del sistema y recursos para ser utilizados en los eventos. La descripción del modelo se realiza a continuación.

\subsection{Generación de entidades}

El modelo de la construcción del proyecto, inicia a través de una interfaz con Microsoft Excel como se mencionó anteriormente. Desde Excel se trabaja con un archivo que simula el inicio de cada una de las zapatas, donde el responsable de planear el proyecto ingresa de forma manual la fecha de inicio y su ubicación en el plano según las coordenadas $(X Y)$, en un archivo que mediante la herramienta Visual Basic (previamente creado) asigna el tipo de zapata entre los 7 disponibles, el tipo de columna, entre los 10 disponibles, indica a que zona del proyecto pertenece (mezanine o no mezanine) y finalmente indica cuantas zapatas se comenzaron por día. En la Figura 3 se muestra una vista del archivo de entra-da de los datos de construcción de zapatas:
These data rows are the entrance to Arena model, as well as another file containing material arrival dates to the project, also developed under a Microsoft Excel tool.

- Elaboration of the model in Arena Software, following activity sequences, defined probability distributions and registered resources using basic and advanced tools in the program.

- Validation of obtained information from above stage, by analyzing activities duration and overall activities in the project in comparison with the ones observed at the job-site.

- Creation of new scenarios allowing observation of behavior confronted to variations regarding: ground saturation, footing beginning dates, material arrival dates, and daily resources availability.

\section{Model developmemt}

Arena software works by graphic simulation and counts with analysis modules that create a system composed by entities, which are assigned with attributes, for later individualization when submitted to events in the future. Additionally, variables are assigned reflecting system features to be used in the events. Model description is indicated below.

\subsection{Creation of Entities}

The model of project construction begins with a Microsoft Excel interface, as previously described. An Excel file simulates the beginning of each footing, where the responsible for project design enters ma-nually the beginning date and location in the drawing according to coordinates (XY). A previously created Visual Basic file, assigns the kind of footing among 7 available types; kind of columns among 10 available types; indicates the pertaining project zone (mezzanine or no-mezzanine); and finally indicates the amount of footings began daily. Figure 3 shows a data entry view for footing construction. 


\begin{tabular}{|c|c|c|c|c|c|c|c|}
\hline \multicolumn{8}{|c|}{ ENTRADA MODELO ARENA/ARENA ENTRY MODEL } \\
\hline Tiempo inicial//nitial time & 28/10/2008 & & $\begin{array}{l}\text { Tiempo final/ } \\
\text { Ending time }\end{array}$ & $20 / 11 / 2008$ & & & \\
\hline $\begin{array}{l}\text { Numero de zapatas/ } \\
\text { Number of footings }\end{array}$ & 32 & & & 04:00 p.m. & & & \\
\hline $\begin{array}{l}\text { Numero zap/ } \\
\text { Number of footings }\end{array}$ & FECHA/DATE & $\mathbf{x}$ & $\mathbf{Y}$ & $\begin{array}{l}\text { IDENTIFICACION }(X Y) / \\
\text { IDENTIFICATION }(X Y)\end{array}$ & $\begin{array}{c}\text { TIPO ZAPATA/ } \\
\text { TYPE OFF FOOTING }\end{array}$ & $\begin{array}{c}\text { TIPO COLUMNA/ } \\
\text { TYPE OF COLUMN }\end{array}$ & \begin{tabular}{|l|} 
MEZZO NÓ MEZZ| \\
MEZZOR NO MEZZ
\end{tabular} \\
\hline 1 & $28 / 10 / 2008$ & 1 & 1 & 11 & 2 & \begin{tabular}{|l|}
1 \\
\end{tabular} & NO MEZZ \\
\hline 2 & $29 / 10 / 2008$ & 1 & 2 & 12 & 5 & 3 & NO MEZZ \\
\hline 3 & $29 / 10 / 2008$ & 1 & 3 & 13 & 5 & 3 & NO MEZZ \\
\hline 4 & $29 / 10 / 2008$ & 1 & 4 & 14 & 5 & 3 & NO MEZZ \\
\hline 5 & $29 / 10 / 2008$ & 1 & 5 & 15 & 5 & 3 & NO MEZZ \\
\hline 6 & $29 / 10 / 2008$ & 1 & 6 & 16 & 5 & 4 & MEZZ \\
\hline 7 & $29 / 10 / 2008$ & 1 & 7 & 17 & 2 & 5 & MEZZ \\
\hline
\end{tabular}

Figura 3. "Vista ventana archivo de entrada"

Figure 3. "Windows view for data entry"

Este archivo constituye la herramienta para alimentar el modelo en Arena, pues a través del mismo se generan los datos de entrada que generan la creación de entidades que corresponden en el caso particu-lar a las zapatas. En esta etapa se utiliza el modulo "Read write" de Arena, que permite la interfaz con Excel. En arena esto se ve reflejado como se aprecia en la Figura 4.

Una vez asignadas las características de la entidad (nombre, ubicación), inicia el proceso constructivo, para lo cual se ingresan datos como: prioridad (para el uso de recursos en cola), la forma de utilizar los recursos en la cual hay cuatro acciones posibles: Delay (demorar), Seize Delay (Tomar demorar), Sei-ze Delay Release (Tomar demorar liberar) y Delay Release (Demorar liberar); también se incluyen los recursos involucrados y la distribución de probabilidad que representa el tiempo de ejecución del mis-mo. Un ejemplo del cuadro de dialogo de esta actividad, se presenta en la Figura 5.
This file is the tool feeding Arena Model, since this tool originates data entry that creates entities corresponding to the specific footings case. In this stage, the Arena "Read write" module is used, which integrates with Excel. In Arena above is reflected as shown in Figure 4.

After the entity features are assigned (name, location), the constructive process begins and data is entered as: priority (for the use of cue resources), the way of employing the resources in which there are four possible actions: Delay, Seize Delay, Seize Delay Release and Delay Release; the involved resources are included as well as the probability distribution that represents the execution time of the process. An example of dialogue box for this activity is shown in Figure 5 .

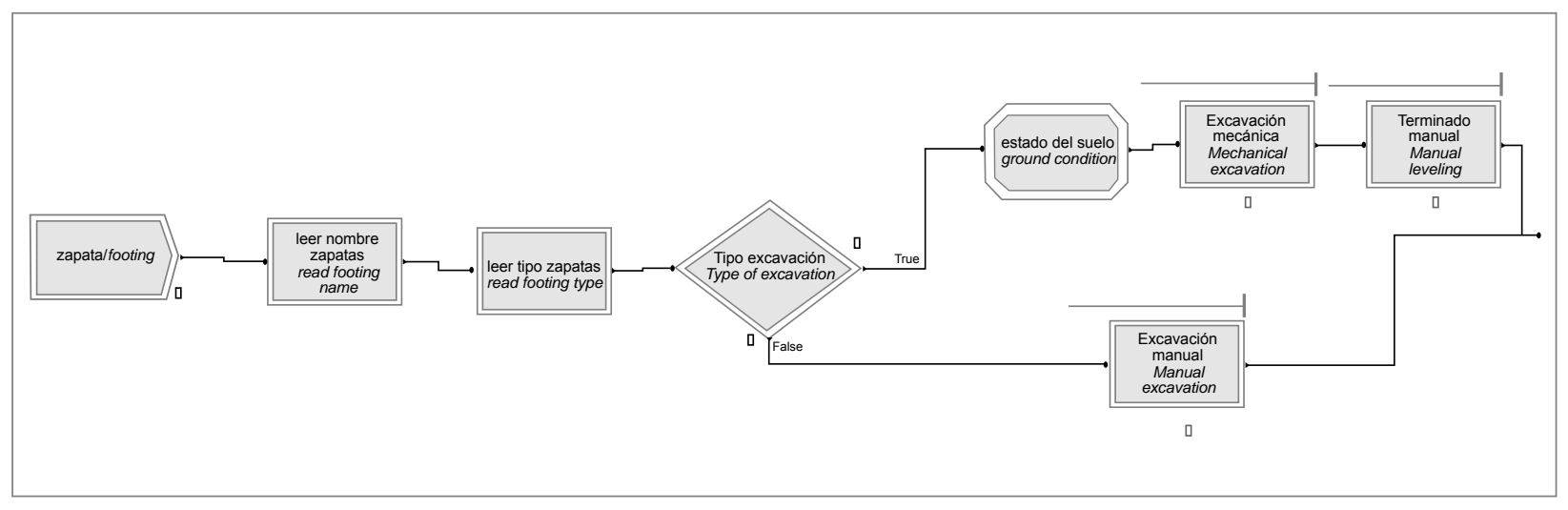

Figura 4. "Vista en Arena del inicio del proceso constructivo"

Figure 4. "Arena view for the beginning of constructive process" 


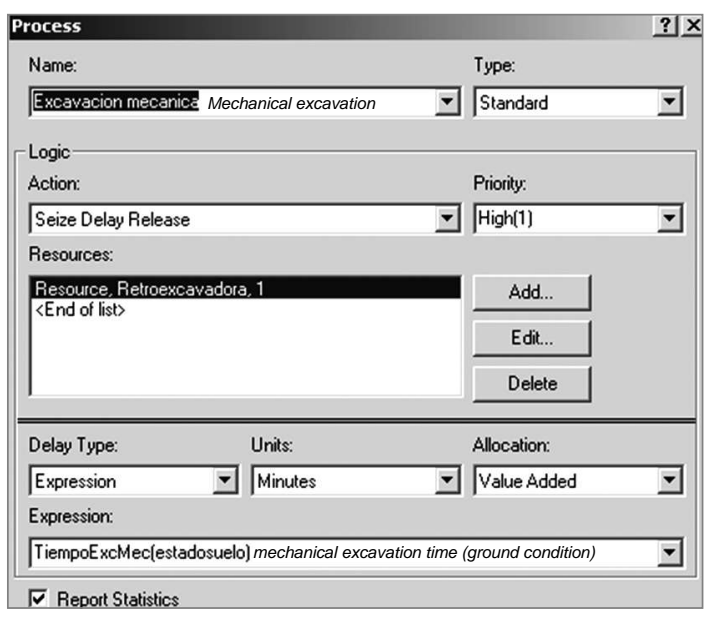

Figura 5. "Vista en Arena del ingreso de un proceso"

Figure 5. "Arena View of an entry process"

\subsection{Llegada de materiales:}

Como los procesos constructivos dependen de la disponibilidad de materiales, se generó una herramienta similar a la descrita en el proceso anterior que a través de la interfaz con Microsoft Excel y el módulo "Read write" crea variables que corresponden a las cantidades de materiales disponibles por día. En esta etapa el planeador del proyecto también ingresa manualmente la fecha de Ilegada de los materiales y las cantidades correspondientes. El modelo lee esta información y cuando posteriormente vayan siendo utilizados los va descontando. Una vista en Arena, donde se refleja la llegada de algunos de los materiales se presenta en la Figura 6.

\subsection{Materials arrival:}

Since constructive processes depend on the availability of materials, a tool similar to the one described above was elaborated to create variables with a Microsoft Excel interface and Read write module, corresponding to the amount of material available per day. In this stage, the project designer also enters manually the arrival date and the corresponding amounts of materials. The model reads this information, and when data are used it discards them. An Arena view that reflects the arrival of some material is shown in Figure 6.

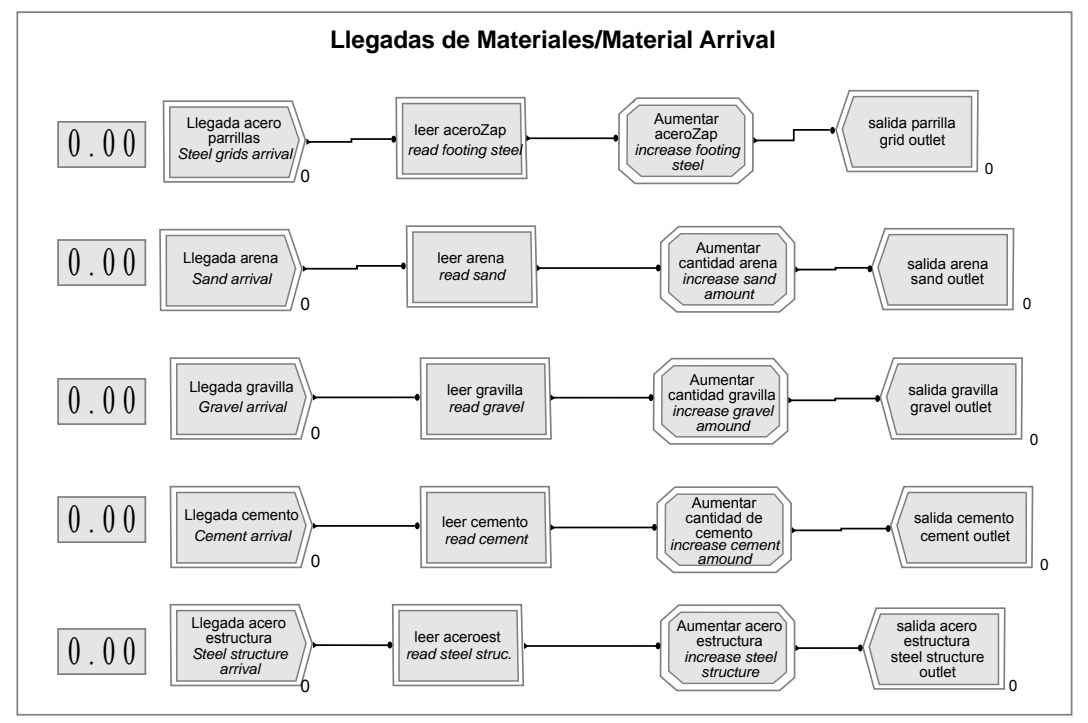

Figura 6. "Vista en arena de llegada de materiales"

Figure 6. "Arena view of material arrival" 


\subsection{Zapatas:}

Una vez el modelo ha generado las entidades y las cantidades iniciales de materiales, comienza la ejecución de procesos iniciando con la construcción de zapatas, cuyo proceso constructivo se observa en la Figura 7.

\subsection{Footings:}

Once the model has created the entities and initial amounts of material, the execution of processes initiates, starting by the footing construction, which process is shown in Figure 7.

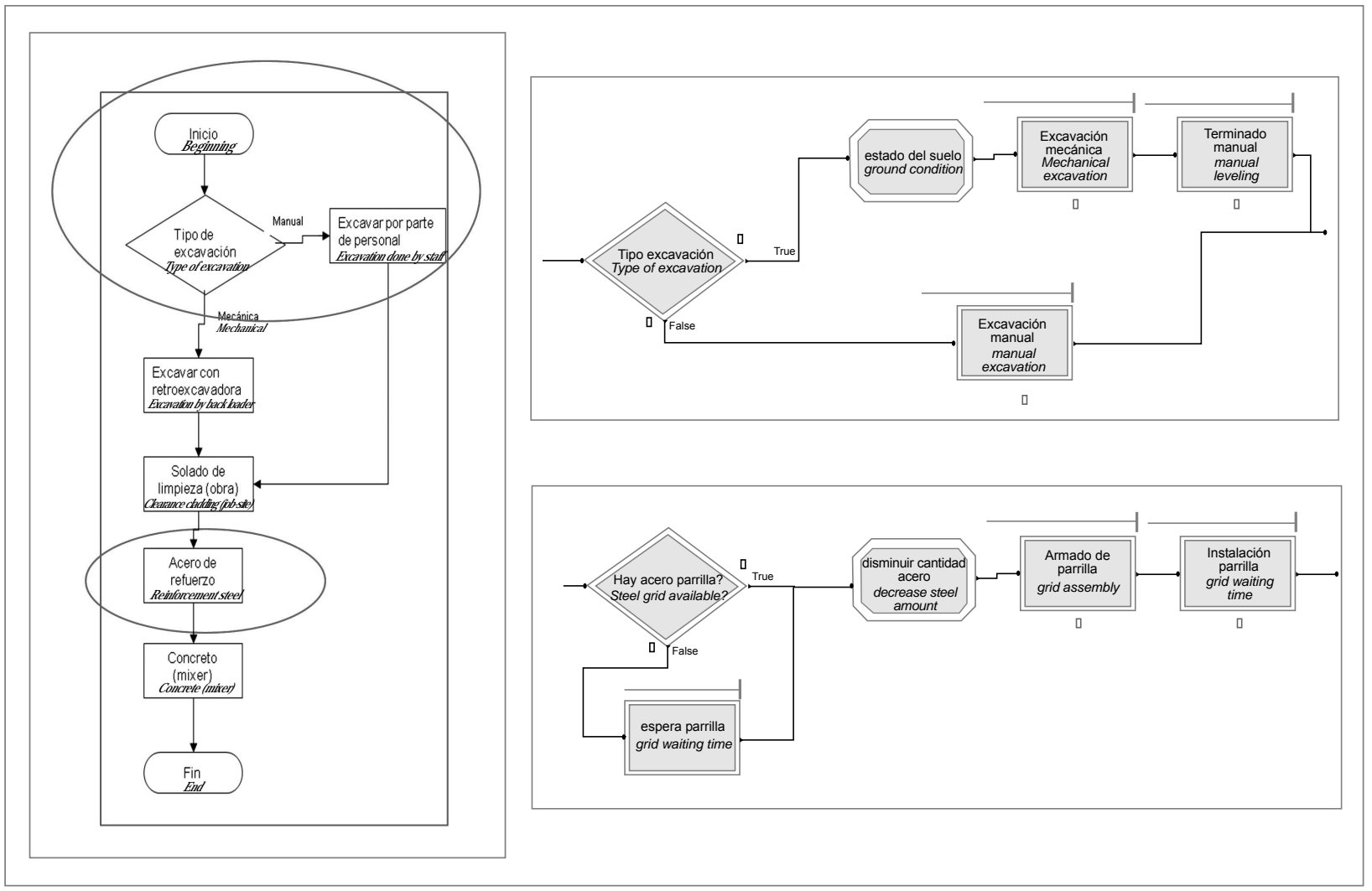

Figura 7. "Proceso constructivo de zapatas"

Figure 7. "Constructive Process of footings"

Como ejemplo se muestra el proceso constructivo de la excavación para las zapatas y de la instalación del acero de refuerzo, simulado en Arena. Como puede observarse en la Figura, el tipo de excavación se incluye como una decisión del modelo, teniendo en cuenta que se realizó de forma mecánica y manual. Así mismo, para la excavación mecánica, se incluyó una variable correspondiente al estado de satura-ción del suelo, ya que según los datos tomados en campo, se obtuvieron tiempos diferentes para suelo saturado y no saturado. Terminada la excavación, se analizan las cantidades de los materiales necesarios para realizar el solado, que corresponden a cemento, gravilla y arena. Esta revisión de inventarios se realiza para todas las ac-tividades donde se requieren materiales disponibles.
As example the constructive processes of footings excavation and installation of reinforced steel are shown, simulated by Arena. As seen on the figure, the type of excavation is included as a decision model, taking into consideration it was mechanically and manually done. In the same way, for mechanical excavation, a variable corresponding to ground saturation conditions was included, since data col-lected at the job-site yielded different times for saturated and non-saturated grounds. Once the excavation is finished, the amount of necessary cladding materials was analyzed, those correspond to cement, gravel and sand. This review of inventories is performed for activities involving material availability. 
El modelo analiza si hay la cantidad necesaria de-pendiendo del tipo de zapata que esté en cola. Si hay suficiente, inicia el proceso o de lo contrario espe-ra hasta que se cumpla la condición. Siguiendo la misma metodología, continúa con el acero para la elaboración de la parrilla y su correspondiente colocación. El siguiente proceso corresponde a la insta-lación del acero de la columna, para lo cual se hace necesario asignar un nuevo atributo, correspondien-te al tipo de columna que se construirá posteriormente. De esta manera el programa verifica que haya inventario de la cantidad de acero necesaria para instalarlo.

\subsubsection{Pedestales}

Esta actividad inicia con asignar un atributo a la entidad, modificándola por pedestal. Inicia con la instalación de flejes del pedestal, encofrado y vaciado de concreto. El proceso constructivo incluido en el modelo de Arena se aprecia en la Figura 8.

Después del vaciado, se genera un tiempo de espera de 1 día para ejecutar el desencofrado y aumentar nuevamente la cantidad de formaleta. En esta actividad, es necesario formar lotes para agrupar los pe-destales dependiendo de la zona donde estén ubicados: mezanine o no mezanine. Así se procede a eje-cutar la actividad de los Ilenos. Estos lotes se forman debido a que los tiempos se tomaron de forma ge-neral y así mismo se considera como una actividad única ya que se hace de manera simultánea y hasta que no se terminen los de un sector no empieza la ejecución de las vigas. La formación de lotes, se forma según se lo indicado en la Figura 9.
The model analyzes whether the amount required is available, depending on the type of footing in cue. If the amount is enough, the process initiates, otherwise it waits until the condi-tions are met. Following the same methodology, the process continues with steel for grillage construc-tion and its later installation. The next step corresponds to steel installation in the column, and then a new attribute needs to be assigned, regarding the type of column to be constructed later. In this way, the program verifies that the inventory has the amount of steel required for the installation.

\subsubsection{Pedestals}

This activity initiates by assigning an attribute to the amount, and then modifying it for each pedestal. It initiates by pedestal hook installation and mold-cast concrete application. The constructive process by Arena is shown in Figure 8.

After casting, a 1-day-standstill time is produced, in order to unmold and increase the camber piece amount again. In this activity, it is necessary to group pedestals by lots, depending on the zone where they are located: mezzanine or no-mezzanine. Thus, the execution of molding activity proceeds. The lots are grouped because times were registered on a general basis, but this is considered as a single activity, since it is simultaneously developed and does not end until one sector is finished, only then the beams construction begins. Lots grouping are done in accordance with Figure 9.

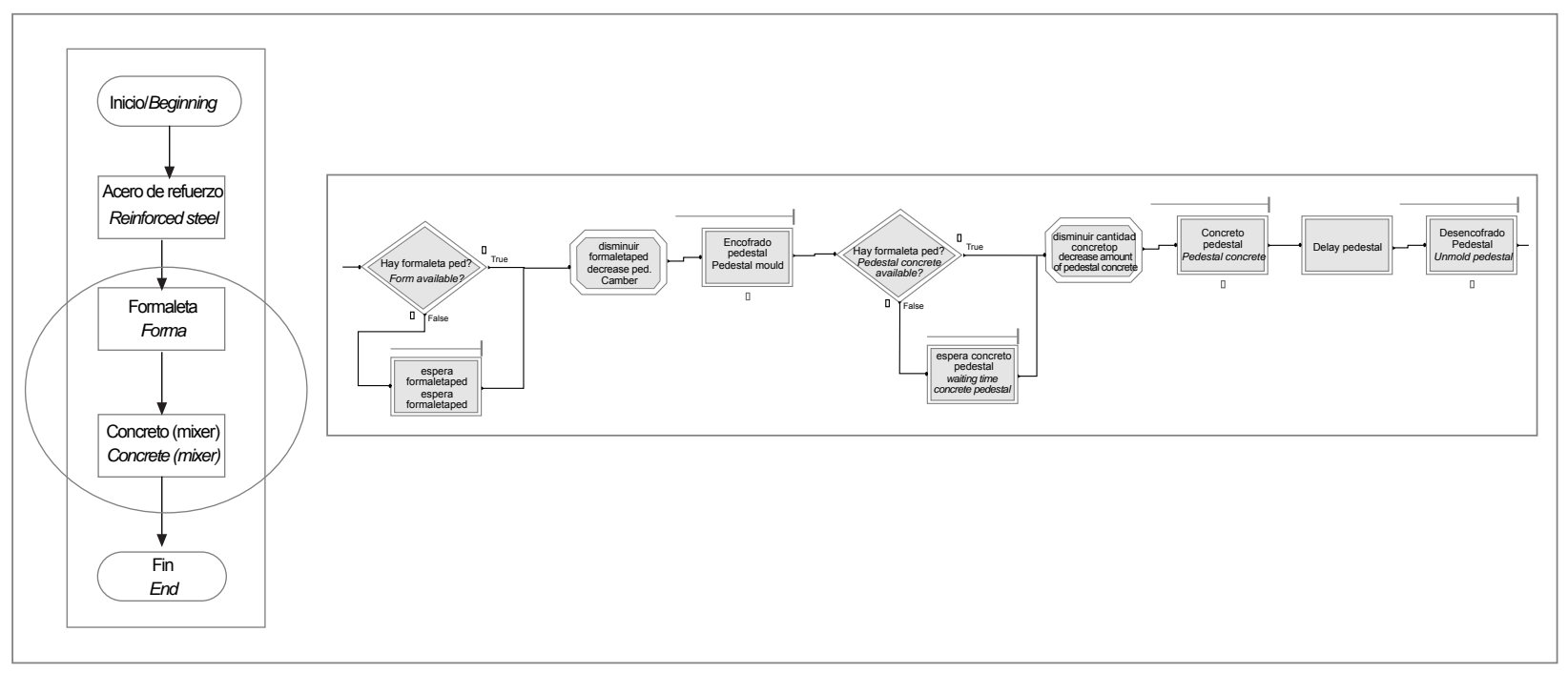

Figura 8. "Proceso constructivo de pedestales"

Figure 8. "Constructive Processes of Pedestals" 


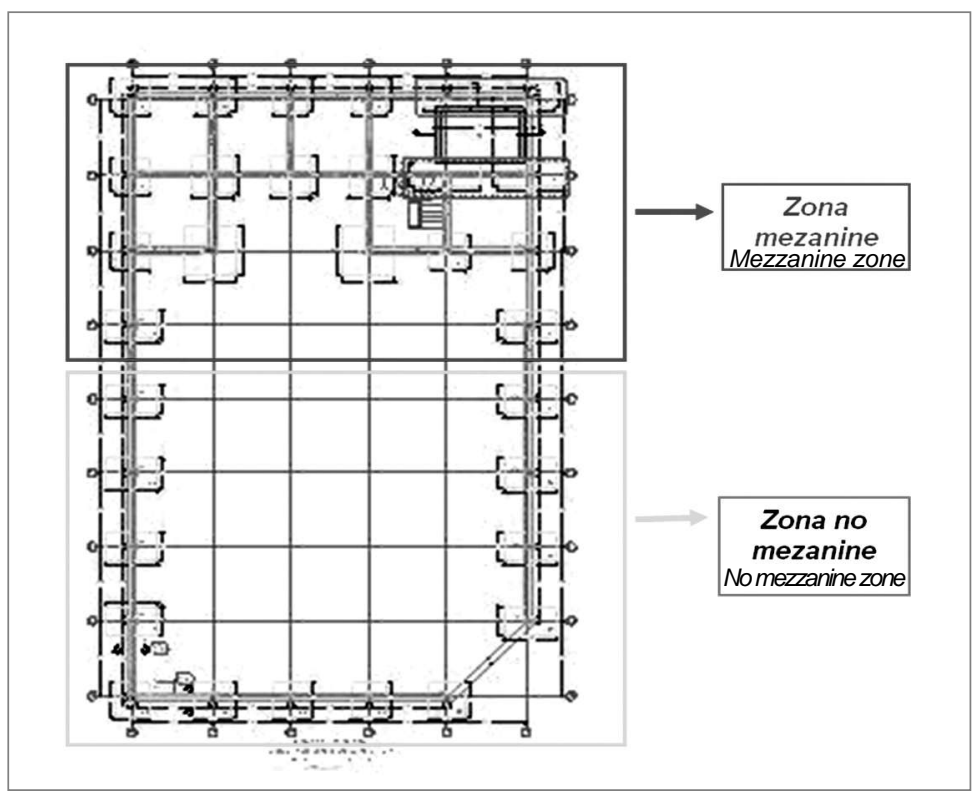

Figura 9. "Zonas mezanine y no mezanine"

Figure 9. "Mezzanine and no mezzanine Zones"

\subsubsection{Vigas de amarre}

Para este proceso, los tiempos se tomaron según los lotes formados para zona de mezanine y no mezanine. Se da prioridad a la zona de mezanine, tal como ocurrió en la obra. Una vez terminadas, se procede a continuar con la zona de no mezanine. Las actividades incluidas son: excavación manual, solado, acero y concreto. En la Figura 10 se observa la división de las entidades según la zona a la que pertenecen:

\subsubsection{Tie Beams}

For this process, times were registered for lots in mezzanine and no-mezzanine zones. Priority is given to mezzanine zone, just as it occurred at the job-site. Once it is finished, the process continues with no mezzanine zone. Activities included are: manual excavation, cladding, steel and concrete. Figure 10 shows entities divisions according to the pertaining zone:

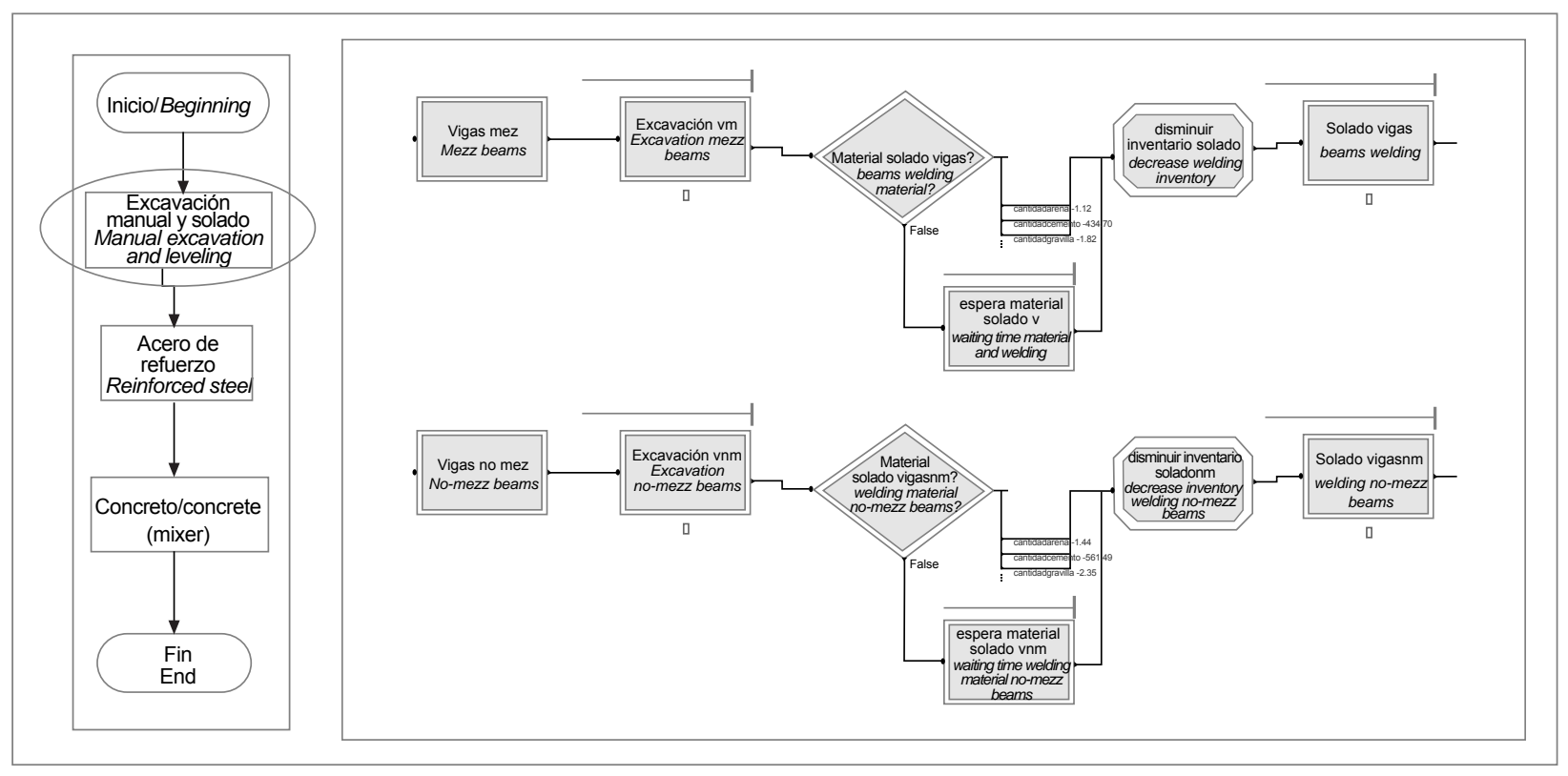

Figura 10. "Proceso constructivo de vigas de amarre"

Figure 10. "Constructive Process of tie beams" 


\subsubsection{Columnas primer tramo mezanine}

En esta etapa nuevamente se lee desde el archivo de Microsoft Excel el orden de construcción de las columnas de la zona de mezanine, información ingresada manualmente por el planeador del proyecto: Se ingresa la ubicación en el plano, asignando un código numérico de 2 cifras de acuerdo con los ejes X y Y. En el archivo de Microsoft Excel se asigna automáticamente el tipo de columna. En el software Arena, se lee esta información utilizando el módulo "Read write" y se asignan así, el nombre de la co-lumna, dado por su ubicación y el tipo. Posteriormente se realiza la revisión del inventario de material y se ejecutan las actividades de acero, encofrado y vaciado de concreto. Después del vaciado, se genera un tiempo de espera de 1 día para ejecutar el desencofrado y aumentar nuevamente la cantidad de formaleta de columnas. Al final de esta etapa, se forma un lote con las 19 columnas de la zona de mezanine para que una vez terminadas, se proceda a construir la placa de entrepiso. Esto se observa en la Figura 11.

\subsubsection{Columnas zona no mezanine}

En esta etapa nuevamente se lee desde el archivo de Microsoft Excel el orden de construcción de las columnas de la zona de no mezanine, establecido inicialmente por cómo se construyeron en el proyec-to, tal como se explicó en el ítem anterior. El proceso inicia con la revisión del inventario de material y se ejecutan las actividades de acero, enconfrado y vaciado de concreto. Después del vaciado, se genera un tiemo de espera de 1 día para ejecutar el desencofrado y aumentar nuevamente la cantidad de forma-leta de columnas. Esta actividad se termina cuando se han ejecutado las $\mathbf{1 3}$ columnas de esta zona.

\subsubsection{Mezzanine columns in the first section}

In this stage, the sequence for construction of columns in mezzanine zone is read from the Microsoft Excel file, such information was manually entered by the project designer: location in the drawing is entered assigning a 2-figures-numeric-code, in accordance with $X$ and $Y$ coordinates. The type of column is immediately assigned for the Microsoft Excel file. Arena software reads this information by using the "Read Write" model and thus assigns the column a name, given in accordance with its location and type. Later a review of material inventory is developed and activities for steel, concrete molding and casting are conducted. After casting, a 1day-standstill time is produced, in order to unmold and increase the camber piece amount in columns again. At the end of this stage, a 19-columns lot is formed in the mezzanine zone, when this lot is finished, the construction of the slab will proceed. This is observed in Figure 11.

\subsubsection{No mezzanine columns}

In this stage, the sequence for construction of columns in no mezzanine zone is read from the Microsoft Excel file, initially established as they were constructed in the project, just as explained in above item. The process initiates by the review of material inventory and activities for steel, then concrete molding and casting activities are conducted. After casting, a 1-day-standstill time is produced, in order to unmold and increase the camber piece amount in columns again. This activity ends when the 13 columns in the zone have been finished.

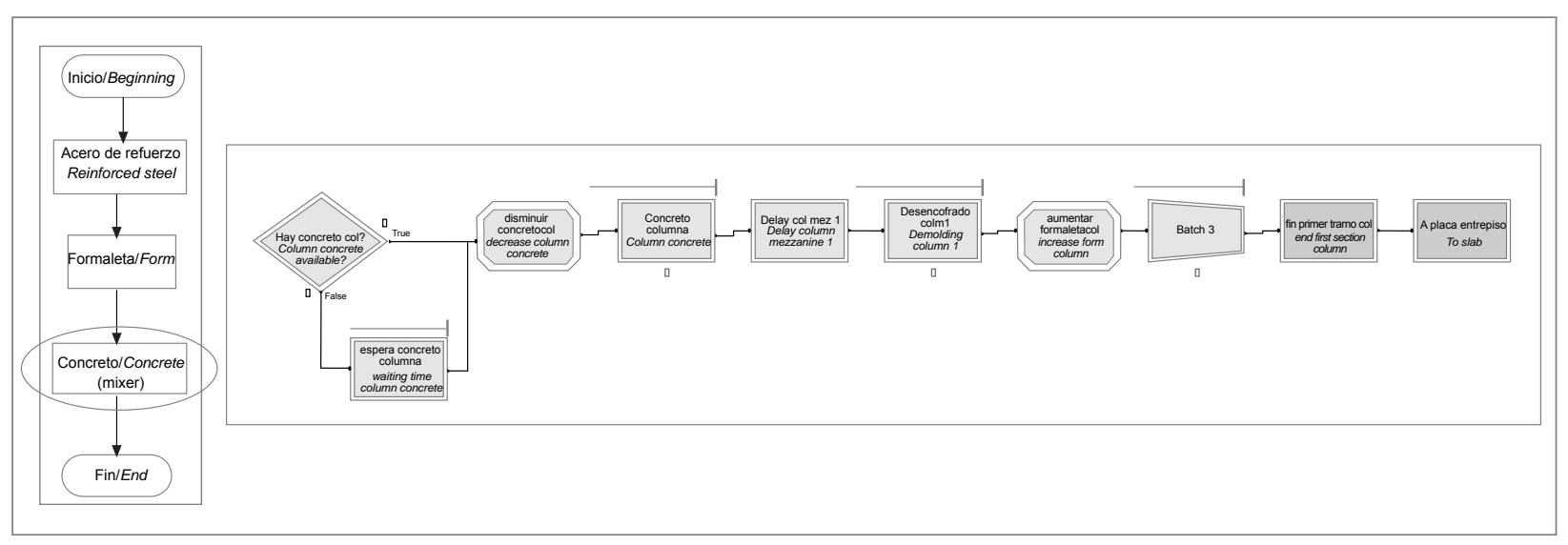

Figura 11. "Proceso constructivo de columnas primer tramo columnas zona mezanine" Figure 11. "Constructive Process of columns in the first section Mezzanine zone 


\subsubsection{Placa de entrepiso}

En este proceso, se mantiene el lote que se había formado con las columnas ya que la placa es una sola entidad (véase la Figura 12). Así se analizan los inventarios de material en cada caso, ejecutando los procesos de: armado de camillas, armadura de placa, acero de placa, testeros, casetones, malla electro soldada y vaciado de concreto.

\subsubsection{Columnas segundo tramo mezanine}

Una vez finalizada la placa, se procede a ejecutar el segundo tramo de las columnas de la zona de mezanine, para lo cual se procede a leer desde el archivo de Microsoft Excel ( de manera similar a los an-teriores ejemplos) el orden de construcción del segundo tramo de las columnas de la zona de mezanine. Posteriormente se realiza la revisión del inventario de material y se ejecutan las actividades de acero, enconfrado y vaciado de concreto. Después del vaciado, se genera un tiempo de espera de 1 día para ejecutar el desencofrado y aumentar nuevamente la cantidad de formaleta de columnas. Esta actividad se termina cuando se han ejecutado las columnas de esta zona y así mismo finaliza la simulación. Una vista final de esta actividad se puede observar en la imagen de la Figura 13.

\subsubsection{Slab}

In this process, the lot formed with columns is kept, since the slab is a single entity (see Figure 12). Thus material inventories are analyzed for each case, conducting the processes of assembling batter boards, slab assembling, and slab steel, end posts, coffers, welded-wire grid and concrete casting.

\subsubsection{Mezzanine columns in the second section}

When the slab is finished, the second section of mezzanine columns is executed. Thus, we proceed to read from the Microsoft Excel file (in similar way to former examples) the construction order for the second section of columns in the mezzanine zone. Later, the material inventory is revised and the activities of steel, concrete molding and casting are developed. After casting, a 1day-standstill time is pro-duced, in order to unmold and increase the camber piece amount in columns again. This activity ends when the columns in the zone have been finished, and in this way simulation process ends. A final view of this activity can be seen in picture, Figure 13.

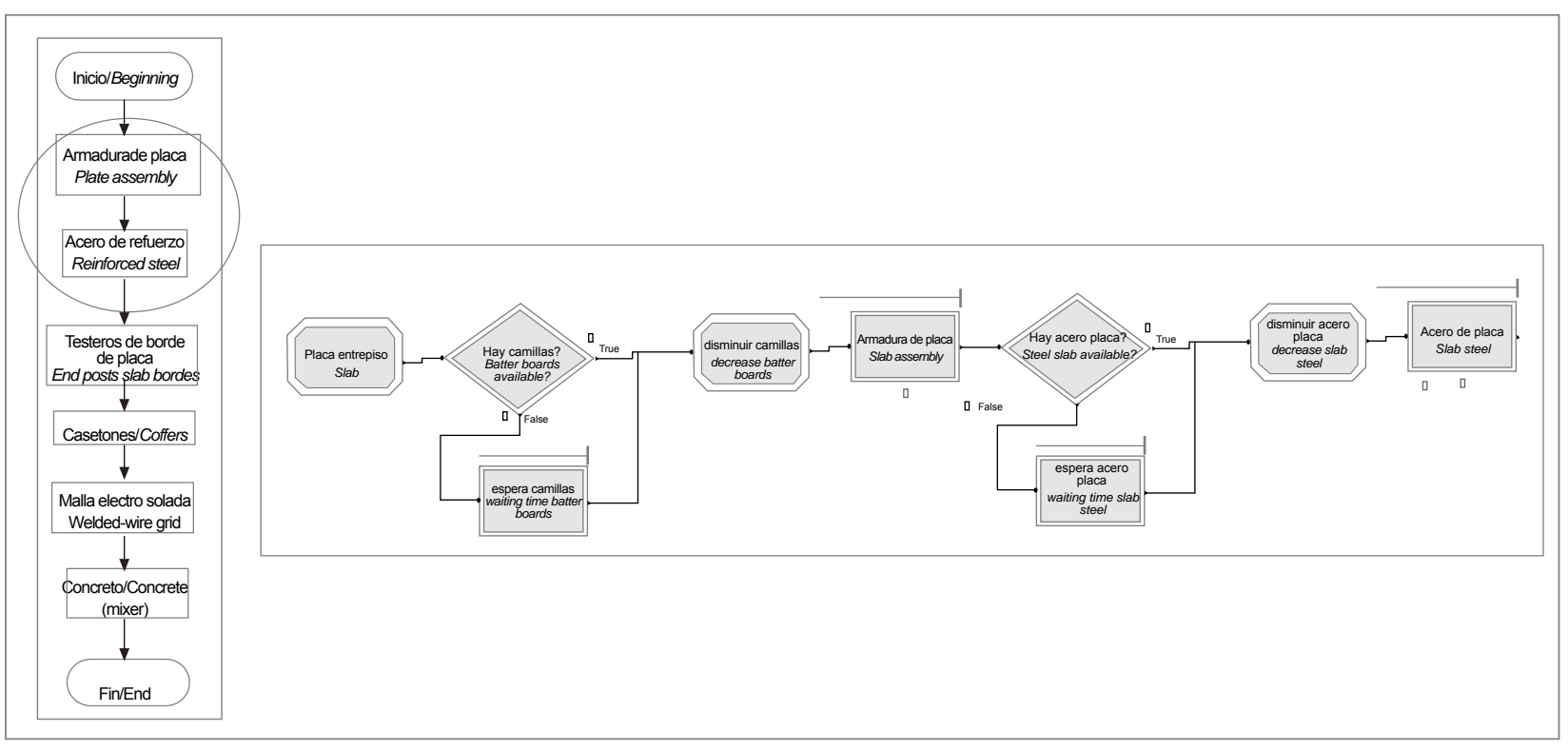

Figura 12. "Proceso constructivo de placa de entrepiso"

Figure 12. "Constructive Process of Slab" 


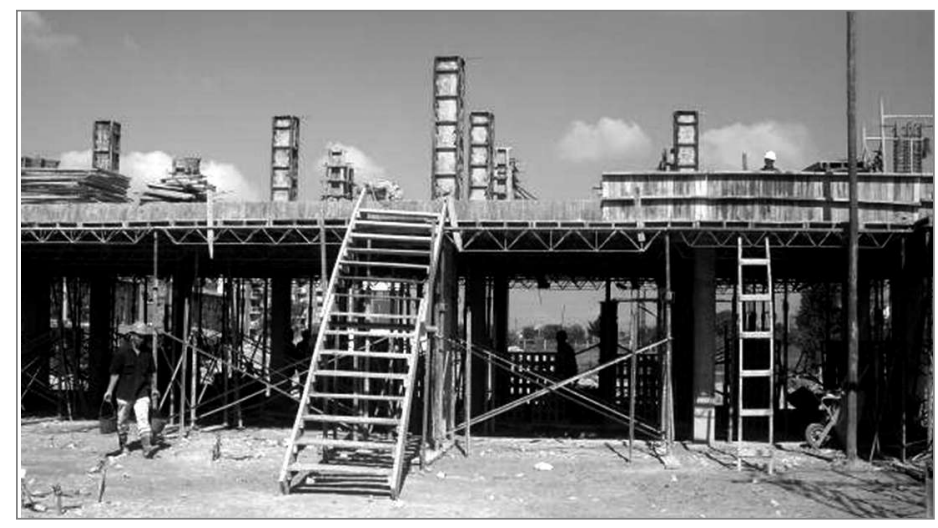

Figura 13. "Vista final del proceso de estructura"

Figure 13. "Final view of structure process"

\section{Numero de corridas y validación estadística (adaptado de banks et al., 2005, Cap. 11)}

Para validar el modelo estadísticamente, se utilizó la metodología de intervalos de confianza que esta-blece que con una precisión específica la longitud media $H$ de un intervalo de confianza de $100(1-\alpha) \%$ para la media, basado en la distribución t, está dado por:

\section{Number of series and statistical validation (adapted from banks et al., 2005, Cap. 11)}

In order to statistically validate the model, the interval confidence methodology was used, which establishes that with a specific accuracy of $\mathbf{H}$ mean longitude for a confidence interval of $100(1-\alpha) \%$ for the mean, based on t-distribution, is given by:

$$
H=t_{\alpha / 2, R-1} \frac{S}{\sqrt{R}}
$$

Ecuación 1. "Longitud media intervalo de confianza" Equation 1. "Mean longitude of confidence interval"

Donde,

$\mathrm{R}$ es el número de replicaciones,

$S$ es la desviación estándar y

t es el valor correspondiente al $\mathbf{9 5} \%$ en la distribución t student.

Para encontrar la precisión deseada debe hallarse un tamaño de replicas $\mathbf{R} \geq \mathbf{R} 0$ que satisfaga $\varepsilon$, que es el error deseado y que se asume como 0.5 días.

\section{Where,}

$R$ is the number of repeated samples $S$ is the standard deviation and $t$ is the value corresponding to $95 \%$ in t-student distribution.

So as to find a desirable accuracy, there must be a number of repeated samples satisfying $e$, which is the expected error, assumed in 0.5 days.

$$
H=t_{\alpha / 2, R-1} \frac{S}{\sqrt{R}} \leq \varepsilon
$$

Ecuación 2. "Longitud media intervalo de confianza para hallar número de réplicas" Equation 2. "Mean longitude for Confidence interval needed to find number of repeated samples" 
Dado que $t_{\alpha / 2, R-1} \geq z_{\alpha / 2}$, siendo $z_{\alpha / 2}$ el valor correspondiente al $95 \%$ en la distribución normal estándar, entonces un estimado inicial de $\mathbf{R}$ está dado por:
Since $t_{\alpha / 2, R-1} \geq_{\alpha / 2}$, being $z_{\alpha / 2}$, the value corresponding to the $95 \%$ in the standard normal distribution, then an $\mathbf{R}$ estimated initial is given by:

$$
R \geq\left(\frac{z_{\alpha / 2} S_{0}}{\varepsilon}\right)^{2}
$$

Ecuación 3. "Estimado inicial de número de réplicas"

Equation 3. "Initial estimated for number of repeated samples"

Se toma una muestra inicial de tamaño $R_{0}$, para obtener un estimado inicial de la desviación estándar $S_{0}$. El número inicial de corridas fue de 9 y se obtuvieron los datos de la Figura 14.
An initial sample is taken for $R_{0}$ size, in order to obtain an initial estimation for $S_{0}$ standard deviation. The initial number was 9 series and data yielded is shown by Figure 14.

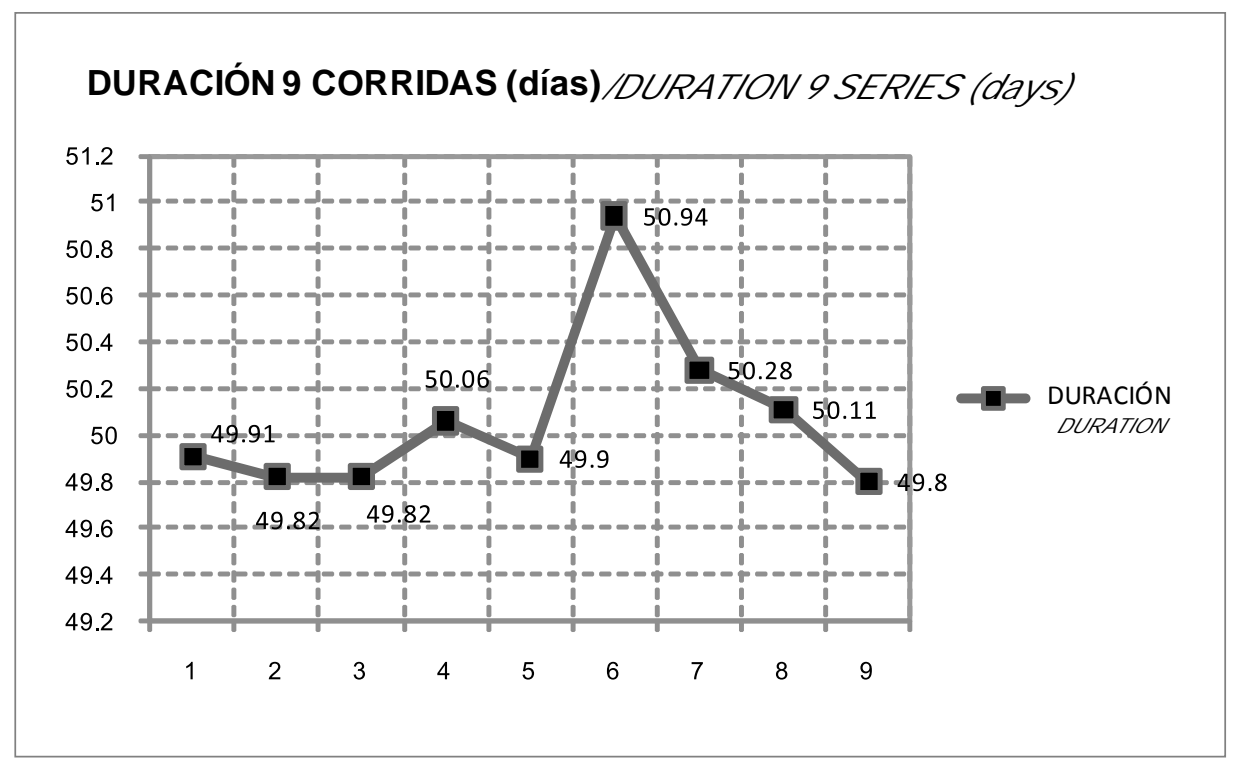

Figura 14. "Resultados para 9 corridas"

Figure 14. "Results for 9 series"

Con estos datos se halla el valor de $\mathbf{R}$ que cumpla con la desigualdad original. El valor de $\left(\frac{z_{\alpha / 2} S_{0}}{\varepsilon}\right)^{2}$ es 2.04, así que se busca un valor de $R$ que sea mayor a este valor, como se ve en la Tabla 1:
From these data, the $R$ value satisfying the original inequality is found. The value for $\left(\frac{z_{\alpha / 2} S_{0}}{\varepsilon}\right)^{2}$ is 2.04, so an $R$ value higher than this is searched, as seen in Table 1.

Tabla 1. "Iteración para encontrar número de corridas"

Table 1. "Interaction in order to find number of series"

\begin{tabular}{|c|c|c|c|}
\hline $\mathbf{R}$ & $\mathbf{3}$ & $\mathbf{4}$ & $\mathbf{5}$ \\
\hline$t_{0.025, R-1}$ & 4.30 & 3.18 & 2.78 \\
\hline$\left(t_{\alpha / 2, R-1} S_{0} / \varepsilon\right)^{2}$ & 9.81 & 5.37 & 4.08 \\
\hline
\end{tabular}


En la Tabla anterior, se puede observar que el valor de $\mathbf{R}$ que satisface la desigualdad original es $\mathbf{R}=\mathbf{5}$. Se corre entonces el modelo 5 veces, para obtener el intervalo de confianza, con la fórmula:
Above Table shows that $R$ value satisfying the original inequality is $\mathbf{R}=5$. The model runs 5 times, in order to obtain the confidence interval by using the formula:

$$
\bar{Y} \pm t_{\alpha / 2, n-1} S / \sqrt{R}
$$

Ecuación 4. "Intervalo de confianza"

Equation 4. "Confidence Interval"

Los resultados de las 5 corridas se aprecian en la Figura 15.
The results from 5 serial runs are shown in Figure 15.

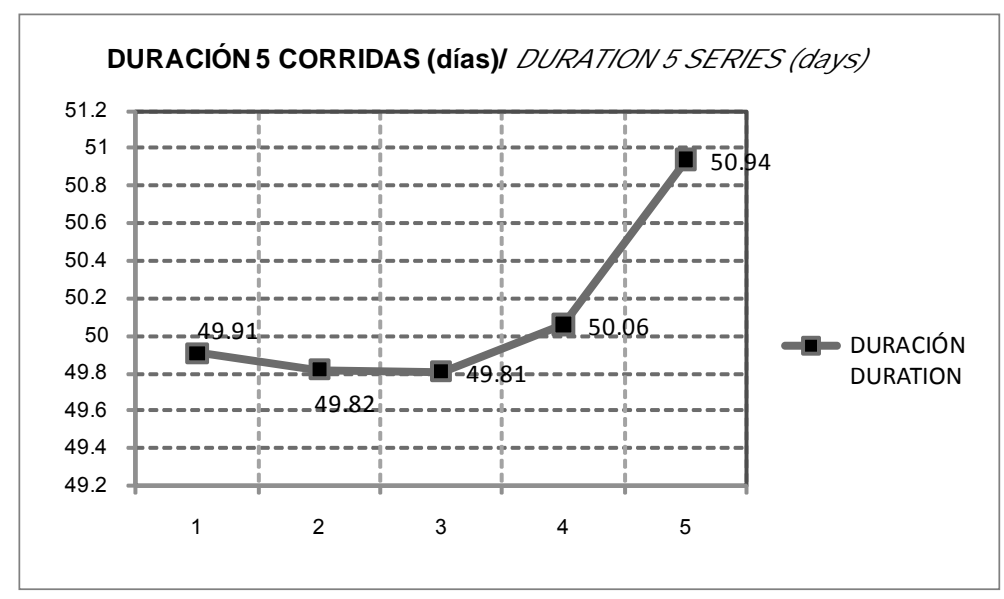

Figura 15. "Resultados para 5 corridas"

Figure 15. "Results for 5 series""

Reemplazando en la fórmula el intervalo de confianza es $[49.81,50.94]$ con una confiabilidad del 95\%. El valor observado en campo es 50.5 días, el cual está incluido en el intervalo de confianza, por lo tanto se valida el modelo. Posteriormente se corrió le modelo 30 veces para aumentar la confiabilidad.

\section{Escenarios}

Con el fin de realizar análisis del proyecto del tipo “¿Qué pasaría si...?”, se plantearon diferentes escenarios que hubieran podido ocurrir, como por ejemplo: contar con los materiales justo cuando se reque-rían, si se hubiera realizado la excavación de todas las zapatas de forma mecánica en suelo saturado (época de lluvias) o lo contrario, si se hubiera realizado la excavación de las zapatas solamente de for-ma manual. Se analizó que pasaba si se construían primero las zapatas de la zona de mezanine y tam-bién que pasaba si se iniciaban 4 zapatas por día de manera ininterrumpida hasta terminar. Estos esce-narios se simularon de acuerdo con la Tabla 2.
By modifying the formula the confidence interval is $[49.81,50.94]$ with a $95 \%$ reliability. The studied value in the job-site is $\mathbf{5 0 . 5}$ days, which is included in the confidence interval, thus validating the mod-el. Afterwards the model was run 30 times to increase reliability.

\section{Scenarios}

In order to develop a kind of "What if......" project analysis, different probable scenarios where created, such as for example: If we had counted with materials just in the required moment; if all foot-ings excavation had been mechanically done on a saturated ground (rainy season); or otherwise, if foot-ing excavation had been manually done only. It was analyzed what would have happened if footings had been constructed at the mezzanine zone first, and what would have happened if 4 footings had been started each day, in an interruptedly way until finishing all of them. These scenarios were simulated in accordance with Table 2 . 
Tabla 2. "Escenarios simulados inicialmente"

Table 2. "Scenarios initially simulated"

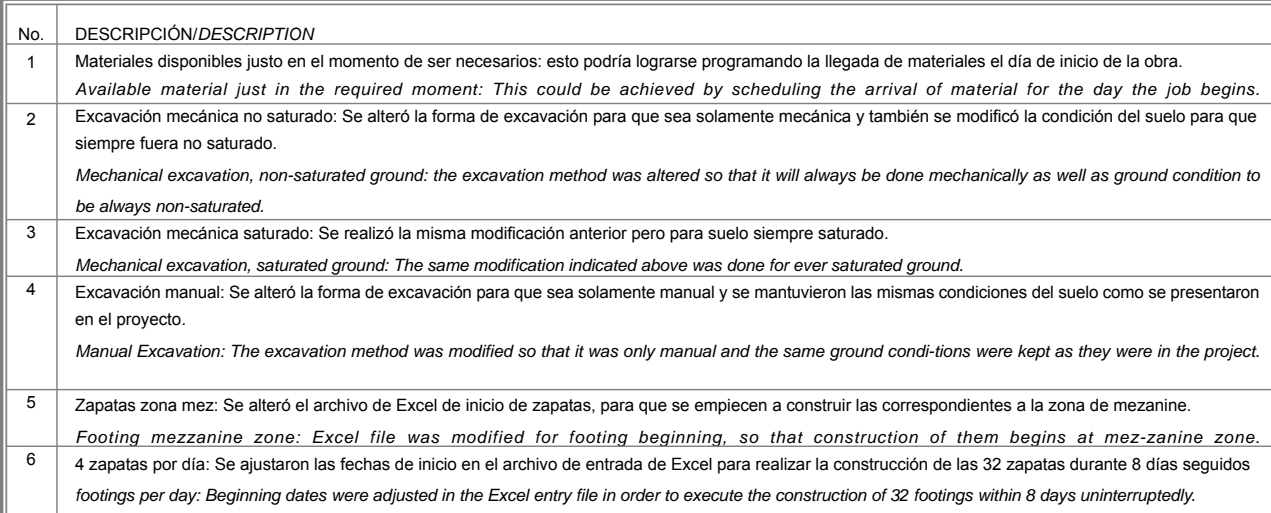

Los resultados respecto a la duración total del proyecto se resumen en la Figura 16.
The results obtained for the total duration of the project are summarized by Figure 16.

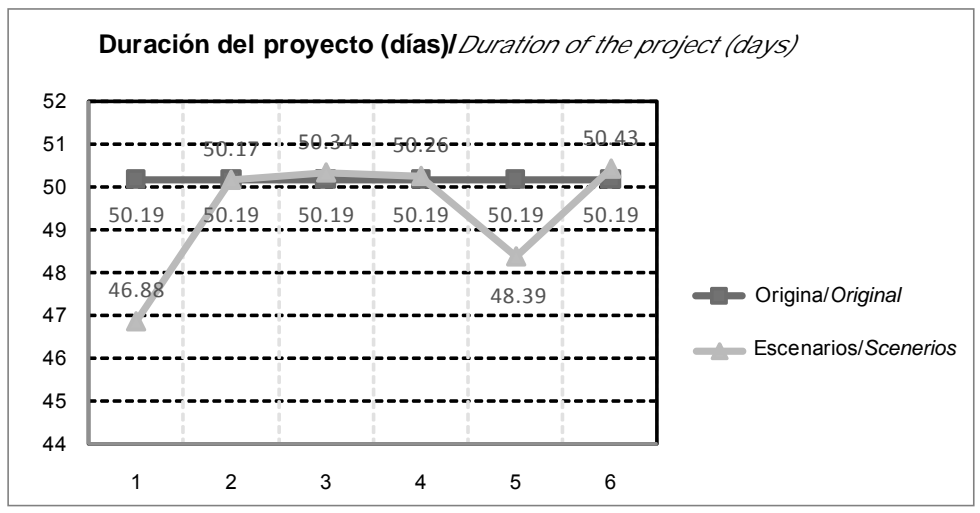

Figura 16. "Duración del proyectos escenarios 1 a 6"

Figure 16. "Duration of the Project - scenarios 1 to 6"

Como puede observarse los escenarios en los que más se minimiza la duración del proyecto fueron contar con los materiales siempre disponibles e iniciar el proyecto por la construcción de las zapatas del mezanine. Con estos se realizaron escenarios en los que se combinaban estas variables que de manera individual habían sido favorables (véase la Tabla 3).

Los resultados respecto a la duración total del proyecto fueron los mostrados en la Figura 17.

Adicionalmente se realizaron escenarios alterando el recurso humano, específicamente en el número de oficiales y ayudantes que participaron en el proyecto. Estos escenarios se ven en la Tabla 4.

Los resultados respecto a la duración total del proyecto se indican en la Figura 18.

Finalmente se realizó una combinación de los escenarios que habían representado mayor disminución en la duración del proyecto como se ve en la Tabla 5 .

Los resultados respecto a la duración total del proyecto se aprecian en la Figura 19.
It can be observed that scenarios showing a greater decrease of project duration were the ones always counting with material availability, and beginning the project by footing construction at mezzanine zone. From this data, scenarios were developed by combining the variables that had been individually favorable. (ref. Table 3).

The results regarding the total duration of the project were shown in Figure 17.

Additionally, scenaries were created by modifying human resources, specifically the number of officers and assistants involved in the project. These scenaries are shown in Table 4.

The results regarding the total duration of the project were shown in Figure 18.

Finally a combination of scenaries showing greater decrease for project duration was made, as shown in Table 5.

The results regarding the total duration of the project were shown in Figure 19. 
Tabla 3. "Escenarios con variables combinadas"

Table 3. "Scenarios with combined variables"

\begin{tabular}{||c|l||}
\hline No. & DESCRIPCIÓN/DESCRIPTION \\
\hline 7 & $\begin{array}{l}\text { Combinación escenario } 5 \text { y 6: Inicio } 4 \text { zapatas por día + inicio zona mez } \\
\text { Combination scenaries 5 and 6: Construction 4 footings a day + beginning at mezz zone. }\end{array}$ \\
\hline 8 & $\begin{array}{l}\text { Combinación escenario 1 y 5: Materiales siempre disponibles + inicio zapatas zona mez } \\
\text { Combination scenaries 1 and 5: Material always available + footing beginning at mezz zone. }\end{array}$ \\
\hline 9 & $\begin{array}{l}\text { Combinación escenario 1, 5 y 6: Inicio } 4 \text { zap por día + materiales siempre disponibles + inicio zapatas mez } \\
\text { Combination scenaries 1, 5 and 6: Construction } 4 \text { footings a day + materials always available + beginning at mezz zone. }\end{array}$ \\
\hline
\end{tabular}

Tabla 4. "Escenarios recurso humano"

Table 4. "Scenarios for Human Resources"

\begin{tabular}{||c|l||}
\hline No. & DESCRIPCIÓN/DESCRIPTION \\
\hline 10 & $\begin{array}{l}\text { Aumento del recurso humano (25 ay }-10 \text { of) } \\
\text { Human Resources Increase (25 ass. }-10 \text { off.) }\end{array}$ \\
\hline 11 & $\begin{array}{l}\text { Aumento del recurso humano (30 ay }-15 \text { of) } \\
\text { Human Resources Increase (30 ass. }-15 \text { off.) }\end{array}$ \\
\hline 12 & $\begin{array}{l}\text { Aumento del recurso humano (40 ay } 20 \text { of) } \\
\text { Human Resources Increase (40 ass. }-20 \text { off.) }\end{array}$ \\
\hline
\end{tabular}

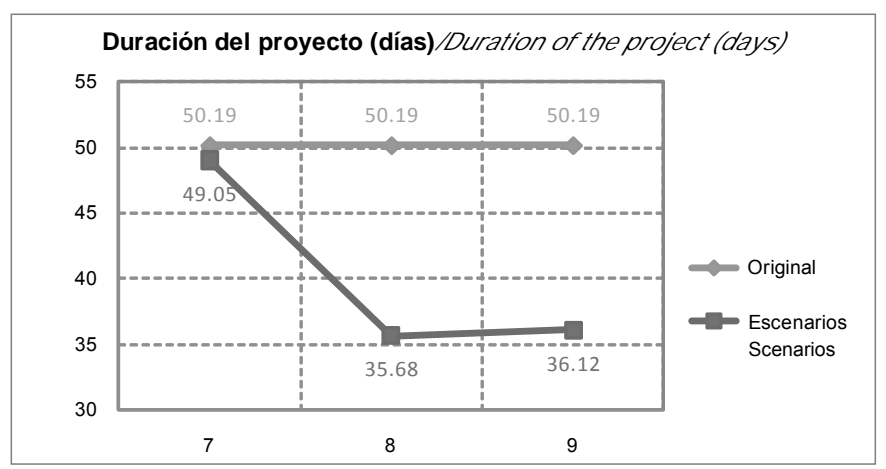

Figura 17. "Duración del proyectos escenarios 7 a 9"

Figure 17. "Duration of projects - scenarios 7 to 9"

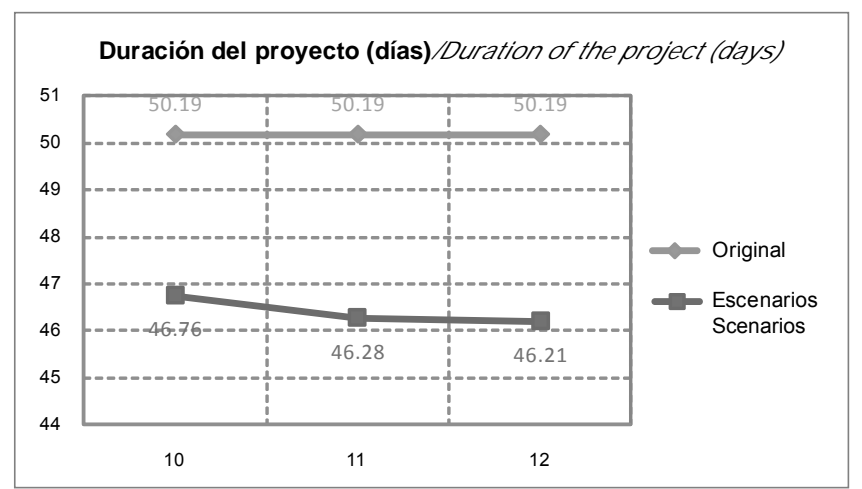

Figura 18. "Duración del proyectos escenarios 10 a 12"

Figure 18. "“Duration of projects - scenarios 10 to 12 "

Finalmente se realizó una combinación de los escenarios que habían representado mayor disminución en la duración del proyecto como se ve en la Tabla 5 .
Finally a combination of scenarios showing greater decrease for project duration was made, as shown in Table 5

Tabla 5. Escenarios que habían representado mayor disminución Table 5. Scenarios showing greater decrease

\begin{tabular}{||c|l||}
\hline No. & DESCRIPCIÓN/DESCRIPTION \\
\hline 13 & $\begin{array}{l}\text { Materiales siempre disponibles + inicio zapatas mezanine + Recurso humano (30 ay }-15 \text { of) } \\
\text { Materials always available + beginning with mezz footings + Human Resouces (30 ass. }-15 \text { off.) }\end{array}$ \\
\hline 14 & $\begin{array}{l}\text { Materiales siempre disponibles + inicio zapatas mezanine + Recurso humano (40 ay }-20 \text { of) } \\
\text { Materials always available + beginning with mezz footings + Human Resouces (40 ass. }-20 \text { off.) }\end{array}$ \\
\hline
\end{tabular}


Los resultados respecto a la duración total del proyecto se aprecian en la Figura 19.
The results regarding the total duration of the project were shown in Figure 19.

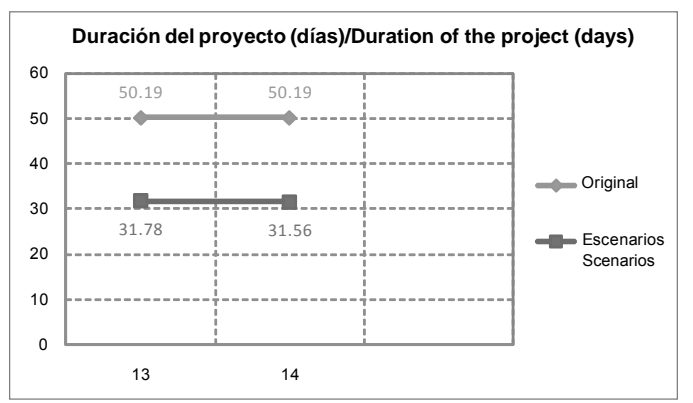

Figura 19. "Duración del proyectos escenarios 13 y 14"

Figure 19. "Duration of projects - scenarios 13 to 14 "

Para el análisis de los escenarios se ejecutaron en Arena 30 réplicas, con el fin de aumentar la confiabilidad de los resultados.

\section{Conclusiones y recomendaciones}

- La simulación de procesos constructivos en el software Arena arrojó resultados similares a los observados en el proyecto estudiado, la diferencia en el modelo original es de menos de un día; por esta razón se considera que es aplicable y útil para este tipo de procesos y su utilización puede convertirse en una herramienta eficiente para la planeación de proyectos de construcción.

- En el análisis de escenarios puede observarse que el tipo de excavación no afecta de manera significativa la duración total del proyecto, la disminución en tiempo en todos los casos es infe-rior a 1 día.

- En el caso real, la disponibilidad de materiales fue un factor de atraso ya que al inicio del mismo hubo una espera de una semana en la llegada de estos. El escenario 1 en el que se mantienen to-das las variables iguales al modelo original y solamente se cambia la fecha de disponibilidad de materiales representa una disminución de 3.62 días.

- Respecto a la zona de inicio de zapatas, si se construyen primero las correspondientes a la zona del mezanine y se mantienen las demás variables iguales al modelo original, el modelo arroja una disminución de 2.11 días.

- Otro aspecto analizado fue el de aumentar el número de zapatas que inician por día y mantener un número constante de 4, sin embargo, esta variable representó una disminución de 0.07 días.

- El recurso humano fue una variable significativa en el proyecto, el número de ayudantes estuvo en el rango de 6 a 28 y el de oficiales entre 1 y 7 . En los escenarios 10, 11 y 12 se mantuvo el número de oficiales y ayudantes constante y se registraron disminuciones de 3 a 4 días.
For the scenarios analysis, 30 repeated samples were executed by Arena, in order to increase the reliability of results.

\section{Conclusions and recommendations}

- The simulation of constructive processes by Arena software yielded similar results to the ones observed from the actual project under study, the difference with the original model is less than one day; for this reason the simulation is considered as applicable and useful in this kind of processes and its execution may become an effective tool in construction projects planning.

- The scenarios analysis indicates that the type of excavation does not significantly affect the total duration of the project, for all cases time decrease is less than one day.

- In the actual case, material availability was a determinant delay factor, since at the beginning there was a oneweek delay until the arrival of materials. Scenario 1 keeps all variables the same as in the original model, only modifying the material availability date, and decreasing in 3.62 days.

- Regarding footing beginning zone, if the ones corresponding to mezzanine zone are constructed first and the other variables are kept the same as in the original model, this model yields a de-crease of $\mathbf{2 . 1 1}$ days.

- Another analyzed fact was the increase of footing number constructed per day, kept at a con-stant number of 4; however, this variable represented a decrease of 0.07 days.

- Human resource was a significant variable in the project, the number of assistants was in the range of 6 to 28 , and officers between 1 and 7 . In scenarios 10, 11, 12 the constant number of officers and assistants was kept and decreased from 3 to 4 days. 
- Con las variables que representaron mayor disminución en días de manera individual se genera-ron nuevos escenarios con combinaciones de las mismas; así se obtienen mayores beneficios en el escenario de materiales siempre disponibles, inicio de zapatas de la zona de mezanine y aumento del recurso humano (40 ayudantes - 20 oficiales) de 18.94 días.

- La interfaz del software Arena con la herramienta Microsoft Excel y a su vez el empleo de ma-cros basados en Visual Basic facilitan el uso del modelo por un usuario externo que está fami-liarizado con herramientas de Windows, a través de las cuales ingresa datos como fechas de ini-cio de zapatas, orden de construcción de elementos y llegada de los materiales.

- La simulación de eventos discretos se basa en datos reales observados en campo, lo cual repre-senta una ventaja sobre otros métodos de planeación de proyectos puesto que se tienen en cuen-ta resultados de tiempos y recursos de una misma empresa lo cual representa una mayor confia-bilidad respecto a otros métodos como la planeación con base en bases de datos comerciales.

- La simulación de procesos constructivos puede aplicarse como una herramienta para la gestión del conocimiento en construcción, ya que se pueden generar modelos de procesos constructivos desarrollados por expertos, que puedan ser empleados en futuros proyectos y se mantenga así un registro del conocimiento de la empresa y de las lecciones aprendidas en cada obra.
- By using the variables yielding greater individual decrease days, new scenarios were created by means of a combination of them, thus greater benefits are obtained in the following scenarios: always available material scenery, beginning of footing construction at mezzanine and human resource increase (40 assistants - 20 officers), yielding an 18.94 days decrease.

- The interaction between Arena software and Microsoft Excel tool, as well as the use of macros based on Visual Basic, enables the use of the model by an external user well acquainted with Windows tools, who enters data as footing beginning date, sequence of element construction and arrival of materials.

- The simulation of discrete events is based on actual data observed in the field, thus representing an advantage over another project planning methods, because time results and resources are ob-tained only from one company, thus providing greater reliability in comparison to other planning methods based on commercial data bases.

- The simulation of constructive processes may be used as a construction knowledge management tool, as constructive processes models created by experts might be used in further projects, pro-viding a company's knowledge record including the lessons they have learnt from each job-site.

\section{Referencias / References}

Baeza J., Arcudia C. E. y Gonzalez J. (2004), Simulación estocástica de rendimientos de mano de obra en procesos de construcción. En: Revista Académica de la Facul-tad de Ingeniería Universidad Autónoma de Yucatán. Volumen 8. Número 2. Mayo - Agosto 2004.

Chang Wah -Ho y Lu Ming (2008), Materials Handling System Simulation in Precast Viaduct. En Journal of Construction Engineering and Management $@$ ASCE. ABRIL/ 300.

Construction: Modeling, Analysis, and Implementation (2008), En Journal of Construction Engineering and Management $\bigodot^{\circ}$ ASCE. APRIL / 301.

Echeverry Diego, Paez Holmes y Mesa Harrison (2008), Simulación digital de procesos de construcción de estructura en concreto: casos de estudio práctico en Bogotá. En Revista Inge-niería de Construcción 2008. Volumen 23 , no. 2. Fabregas Aldo, Wadnipar Rodrigo, Paternina Carlos y Mancilla Alfonso (2003), Simulación de sistemas productivos con Arena. 1 edición. Colombia. Ediciones Uninorte.

Kelton David, Sadowski Randall y Sturrock David (2008), Simulación con software Are-na. 4 ed. México Mc Graw Hill. 631 p. Lopez José Eduardo (1997), Control integral de calidad del concreto compactado con rodillo Control integral de calidad del concreto compactado con rodillo. Bogotá. Tesis de magíster. Uni-versidad de los Andes. Departamento Ingeniería Civil y Ambiental.

Lu Ming et al. (2006), Application Framework for Mapping and Simulation of Waste Handling Proc-esses in Construction. En Journal of Construction Engineering and Management (c) ASCE. NOVEMBER / 1213. 
Lu Ming y Wong Lap-Chi (2009), Comparing PROMODEL and SDESA in modeling construction operations. En Proceeedings of the 2005 Winter Simulation Conference. (Consultado el 30 de enero de 2009) Disponible en http://ieeexplore.ieee.org

Lu Ming (2003), "Simplified Discrete-Event Simulation Approach for Construction Simulation". En Journal of Construction Engineering and Management $(C)$ ASCE / October / 537.

Sacks et al. (2007), LEAPCON: Simulation of lean construction of high-rise apartment buildings. En Journal of Construction Engineering and Management (C) ASCE. JULIO / 529.

Sosa J. A., Baeza J. R. y Arcudia C. E. (2007), Modelo para simulación computarizada del proceso constructivo de la losa prefabricada I-18*. En Revista Ingeniería y Universidad - Pontificia Universidad Javeriana. Volumen 11.

Xiaoming M. y Xueqing Z. (2008), “Construction Process Reengineering by Integrating Lean Principles and Computer Simulation Techniques". En: Journal of Construction Engineering and Management (C) ASCE / May. 